\title{
STRATEGI 7P UNTUK PERLUASAN PANGSA PASAR SEKTOR INDUSTRI PARIWISATA DI DESA EKOWISATA KERUJUK KABUPATEN LOMBOK UTARA
}

\author{
Baiq Nurul Suryawati ${ }^{*}$, Iwan Kusmayadi, Laila Wardani \\ Fakultas Ekonomi dan Bisnis Universitas Mataram \\ Jl. Majapahit 62, Mataram 83125, Lombok - Indonesia \\ *)alamat korespondensi: nurul.suryawati@unram.ac.id
}

\begin{abstract}
ABSTRAK
Program pengabdian kepada masyarakat ini bertujuan untuk memberikan pendampingan kepada para pemilik usaha yang ada di Desa Ekowisata Kerujuk. Dalam usaha memasarkan produknya, para pemilik usaha di desa ekowisata Kerujuk sudah mulai menggunakan beberapa media sosial sebagai alat bantu, seperti instagram, facebook, youtube, whatsapp, twitter bahkan wordpress. Penggunaan media sosial seadanya menyebabkan usaha yang mereka lakukan tidak dapat optimal. Pemberian materi mengenai strategi 7P, yang terdiri dari Product (Services), Price, Place, Promotion, People, Process, dan Physical Evidence, strategi ini ini disebut pula strategi komunikasi pemasaran untuk dapat mengenali pangsa pasar agar dapat memaksimalkan penjualan. Hal ini dilakukan untuk membantu mereka menganalisis permasalahan utama mereka di dalam aspek pemasaran. Program pengabdian kepada masyarakat ini kemudian dapat mengidentifikasi ketidak-mampuan mereka mengenali atribut utama produk mereka, yang akhirnya membuat mereka tidak dapat memetakan konsumen dengan baik sehingga promosi yang mereka lakukan tidak banyak membuahkan hasil. Program pengabdian kepada masyarakat ini, dilaksanakan dengan menggunakan metode intervensi yaitu pemberian ceramah dan tanya-jawab yang bertujuan untuk merubah pemikiran para pemilik usaha sehingga konsep pemasaran yang mereka terapkan dapat menyeluruh sesuai dengan harapan konsumen. Berdasarkan hasil kegiatan pengabdian terhadap masyarakat ini adalah kemampuan untuk menguraikan permasalahan utama dengan memperbanyak saluran disitribusi. Pelaksanaan kegiatan pengabdian kepada msyarakat ini memfasilitasi urun rembug pemilik usaha di desa ekowisata Kerujuk untuk dapat menjalin kerja-sama dengan BUMDES-Mart sebagai sarana peningkatan saluran distribusi untuk peningkatan pangsa pasar.
\end{abstract}

Kata Kunci: Strategi 7P, Saluran distribusi, Pangsa pasar, Desa Ekowisata Kerujuk

64 


\section{PENDAHULUAN}

Usaha di bidang pariwisata, saat ini sangat erat kaitannya dengan perkembangan ekonomi nasional. Usaha ini mempunyai kedudukan, potensi dan peranan yang sangat penting dalam mewujudkan tujuan pembangunan ekonomi. Usaha di industri pariwisata diharapkan mampu menciptakan atau memperluas kesempatan kerja, distribusi pendapatan dan meningkatkan pendapatan masyarakat serta mampu menciptakan stabilitas ekonomi.

Bila kita melihat kejadian kerusuhan dan bencana alam yang sempat melanda perekonomian Indonesia, sebagian usaha pariwisata kendati banyak yang belum bangkit akan tetapi di kemudian hari mampu mempertahankan ketangguhannya dalam menghadapi mundurnya industri pariwisata saat itu. Jika dibandingkan dampak yang ditimbulkan oleh kemunduran atau krisis finansial, sebagian besar industri menengah dan industri besar tidak mampu kembali bangkit dan mempertahankan usahanya.
Pembinaan

dan

pengembangan industri pariwisata memang mendapat perhatian pemerintah dan swasta. Bentuk perhatian diwujudkan dalam upaya pembinaan dan pengembangan seperti penyuluhan, pendidikan pelatihan, motivasi, konsultasi, studi banding serta dalam bentuk lainnya yang mengarah pada perbaikan mutu usaha. Lebih lanjut di NTB, desa ekowisata Kerujuk menjanjikan berbagai macam potensi untuk dapat dikembangkan menjadi usaha. Dengan adanya banyak jenis usaha di bidang pariwisata, banyak pula masyarakat yang dapat terlibat di dalamnya. Kesempatan ini pun dapat menjadi sumber mata pencaharian utama, seperti membuat guest house, fasilitas kegiatan outbond seperti flying fox, dan sebagainya.

Melihat kecenderungan masyarakat, umumnya masyarakat menjadi pasif dengan hanya mengandalkan potensi alam saja, tanpa lebih lanjut menerapkan berbagai strategi pemasaran untuk menciptakan keunggulan bersaing. Hal ini dilakukan karena bisnis dianggap 
mudah dan tidak memerlukan keterampilan khusus, hanya mengandalkan intuisi saja. Dikarenakan banyaknya penduduk yang menjalankan usaha yang sama, maka persaingan menjadi ketat dan keuntungan justru sulit untuk didapat. Potensi-potensi usaha yang bergerak di bidang jasa seyogianya dapat dikembangkan untuk mendukung industri pariwisata ini. Oleh karena itu, pendampingan penggunaan strategi 7P terhadap pemilik usaha disekitar daerah wahana ekowisata Kerujuk perlu dilakukan. Urgensi ini mengingat peningkatan pangsa pasar diperlukan untuk keberlangsungan sebuah usaha, terlebih usaha jasa.

Desa ekowisata Kerujuk, merupakan desa yang terletak dekat dengan daerah wisata tiga Gili, yaitu Gili Terawangan, Gili Meno dan Gili Air serta masuk dalam wilayah Lombok Utara. Banyaknya lahan berbukit memungkinkan pengembangan wahana untuk outbond, tidak hanya pengembangan wahana untuk outbond, kondisi tanah perkebunannya layak untuk dikembangkan menjadi desa agrowisata. Kesulitan yang dihadapi para penduduk adalah kurangnya pengenalan terhadap berbagai strategi pemasaran untuk mengenali keunggulan bersaing, serta pengetahuan tentang berbagai variasi usaha yang bergerak di bidang jasa. Selama ini masyarakat sekitar hanya memiliki orientasi menggantungkan pada usaha pariwisata yang sudah ada. Berkenaan dengan situasi tersebut, maka pendampingan ini akan dilakukan untuk membantu penduduk di desa Kerujuk untuk mengembangkan potensi usaha mereka yang bergerak di bidang jasa.

\section{METODE KEGIATAN}

Pemecahan permasalahan pada masyarakat akan dilakukan dengan menggunakan strategi 7P yaitu dengan melakukan pendampingan kepada para pemilik usaha berkenaan dengan penggunaan secara optimal media sosial sebagai sarana pemasaran. Strategi 7P merupakan strategi pemasaran jasa Pemanfaatan media sosial dewasa ini dipandang sebagai salah satu media yang cukup efektif dalam mempromosikan sebuah 
produk, penggunaan media sosial seringkali dilakukan seadanya, sehingga metode intervensi diberikan dengan metode ceramah serta tanyajawab untuk membantu mengatasi permasalahan yang dihadapi oleh para pemilik usaha.

\section{Selanjutnya untuk} membuat sistem yang terpadu dengan penggunaan media sosial, maka para pemilik usaha akan diperkenalkan tentang konsep dasar strategi 7P agar mudah dipahami oleh para pelaku usaha. Pendampingan dilakukan kepada para pemilik usaha, agar mereka dapat mengenali permasalahan mereka dalam melakukan kegiatan bisnis selama ini. Sehingga diharapkan dengan hasil pengabdian kepada masyarakat ini para pemilik usaha dapat melakukan evaluasi diri terkait kegiatan usahanya, dan dapat meningkatkan penjualan dengan memahami jalur distribusi, serta optimal dalam penggunaan internet marketing berbasis media sosial.

Untuk meningkatkan pemasaran jasa melalui internet marketing, maka syarat mutlak yang harus dimiliki adalah kemampuan melakukan promosi melalui media sosial. Penggunaan media sosial yang pada dasarnya tanpa bayar memiliki keterbatasan, para pemilik usaha harus dapat mengelola media sosial mereka secara mandiri, hal itu baik dalam melakukan komunikasi secara online dengan calon pembeli, penggunaan email, penyelesaian transaksi pembayaran sampai dengan proses pengiriman barang ke alamat pembeli. Para pemilik usaha diinformasikan untuk dapat memanfaatkan beberapa situs penjualan online yang telah tersedia, semisal; elevania, tokopedia, bukalapak dan lainnya.

Untuk selanjutnya para pemilik usaha dan tim kegiatan pengabdian kepada masyarakat akan melakukan diskusi tentang pemahaman strategi 7P, dari berbagai konsep yang berkenaan dengan Product, Price, Place, Promotion, Process, People dan Physical Evidence. Salah satu jenis strategi pemasaran adalah strategi bauran pemasaran (marketing mix) yaitu cara untuk mencapai tujuan pemasaran dengan 
melakukan pemenuhan kebutuhan dan keinginan konsumen melalui pertukaran barang dan jasa. Strategi bauran pemasaran dirancang secara terintegrasi untuk menghasilkan respon yang diiginkan dalam pasar sasaran yang terdiri dari product, price, place, promotion, people, process, physical evidence (Herdiana Abdurrahman, 2015).

\section{HASIL DAN PEMBAHASAN}

Kegiatan pengabdian kepada masyarakat dilaksanakan di Rumah Tani Desa Ekowisata Kerujuk. Partisipan mendapatkan informasi yang disampaikan dalam acara pertemuan tersebut berupa materi diskusi yang mencakup beberapa konsep terkait strategi 7P. Tim kegiatan pengabdian kepada masyarakat mengajak para partisipan untuk berdiskusi terkait materi yang sudah disampaikan.

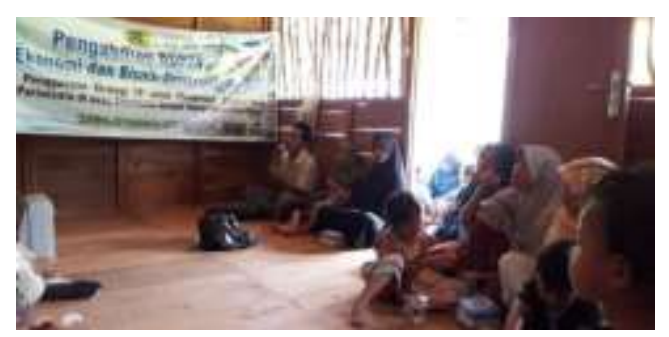

Gambar 1. Sesi Tanya-Jawab dengan Kepala Dusun Kerujuk
Sesi tanya-jawab dimulai dengan permintaan agar diberikan pelatihan lanjutan dikarenakan banyak masyarakat yang mengharapkan agar dilatih sehingga memiliki keterampilan tertentu. Sebagian besar yang dapat menghadiri sesi ini adalah para perempuan, hal ini disebabkan para lelaki hanya satu dua yang dapat meluangkan waktu, sebagian besar walaupun hari libur harus tetap bekerja di kebun. Untuk dapat menghadirkan para lelaki sebagai kepala keluarga, kegiatan pengabdian kepada masyarakat dianjurkan untuk dilakukan di siang hari, hal inilah yang menjadi kendala mengingat lokasi kegiatan pengabdian kepada masyarakat berada di wilayah pegunungan. Kondisi bencana alam terkait gempa yang menimpa daerah ini menyebabkan masyarakat enggan untuk berlama-lama berkumpul di dalam satu tempat.

Untuk memfasilitasi penggunaan media sosial, fasilitator menekankan kelebihan dan kekurangan dari berbagai media sosial. Penggunaan gambar untuk optimalisasi instagram, penggunaan 
bahasa tulisan untuk twitter, penggunaan status untuk whatsapp dan jejaring untuk facebook. Didalam pelaksanaan tatap muka, fasilitator memberikan perangkat akses internet berupa dua (2) buah modem, agar para pemilik usaha dapat dengan mudah mengakses internet. Penggunaan handphone pribadi untuk tethering dan penyediaan akses internet dirasa tidak cukup untuk memudahkan para pemilik usaha.

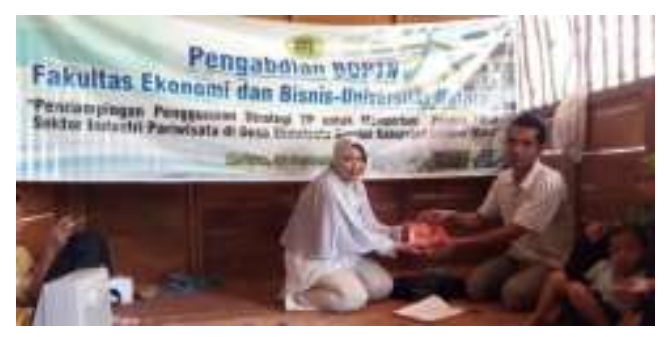

Gambar 2. Penyerahan Modem untuk Kemudahan Akses Internet

Diskusi dilanjutkan

dengan membuka kembali sesi tanyajawab, beberapa pertanyaan muncul dari pemilik usaha minuman tradisional. Selama ini untuk meningkatkan penjualan minuman tradisional air aren, para pemilik usaha telah memodifikasi kemasan. Kemasan yang tersedia untuk dijual saat ini adalah kemasan siap minum dengan botol plastik. Kendati demikian, pada saat pengabdian kepada masyarakat dikarenakan kondisi gempa masyarakat mengalami banyak kerusakan pada aset produksi mereka, pemilik usaha memberikan gambaran bahwa mereka sudah mengikuti berbagai saran yang diberikan oleh pihak pemerintah terkait berkenaan dengan perbaikan kemasan dan pemberian merk. Setelah diuraikan ternyata permasalahan utama tidak terkait dengan product, akan tetapi place yang berkenaan dengan distribusi. Selama ini para pemilik usaha mengandalkan tamu-tamu yang datang untuk memperkenalkan produk mereka, konsep network pun dijelaskan begitu pula pentingnya pencantuman label halal, tanggal produksi serta tanggal kadaluarsa.

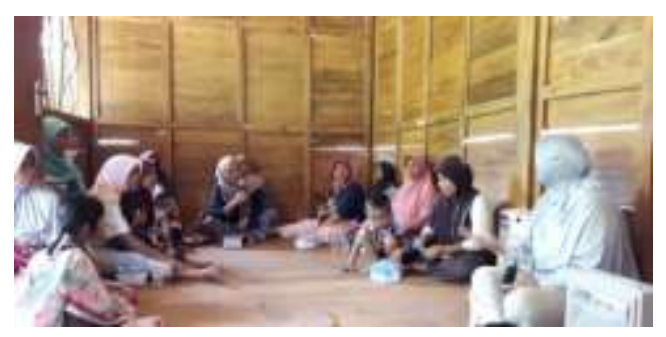

Gambar 3. Sesi Tanya-Jawab dengan Pemilik Usaha Air Aren dalam Kemasan

$$
\text { Hasil diskusi }
$$

menyarankan pentingnya menjalin kerjasama dengan pihak distributor, dalam hal ini BUMDES-Mart agar masyarakat secara luas dapat mengetahui keberadaan air aren dalam kemasan ini. Sebagian besar 
partisipan yang hadir memiliki pendidikan yang rendah akan tetapi partisipan telah terbiasa untuk urun rembug dalam pertemuan kemasyarakatan, seperti kegiatan pembangunan masjid dan sebagainya, maka partisipan tidak segan-segan menunjukkan antusiasme dalam mengikuti kegiatan ini. Partisipan menunjukkan memiliki keinginan untuk maju, hal ini ditunjukkan dengan pertanyaan-pertanyaan yang muncul selama kegiatan. Oleh karena itu, tim pengabdian kepada masyarakat merasa bahwa apabila ada tim khusus yang mendampingi secara intens maka peningkatan ekonomi khususnya untuk daerah Kerujuk yang terdampak gempa ini akan lebih cepat.

Adapun kesulitan yang dihadapi adalah upaya memfasilitasi keinginan partisipan yang sangat mengharapkan adanya pendampingan yang intensif. Kenyataan bahwa tim pengabdian hanya bertugas memfasilitasi peran Perguruan Tinggi untuk dapat membantu masyarakat secara langsung dapat dipahami, kendati demikian dengan tim pengabdian merasakan pentingnya pendampingan yang lebih intensif di lakukan di lokasi tersebut. Pendampingan intensif termaksud adalah penugasan mahasiswa KKN di lokasi tersebut.

\section{KESIMPULAN DAN SARAN}

Kegiatan pengabdian kepada masyarakat, yaitu pengenalan strategi 7P di dusun Kerujuk telah diselesaikan dan dapat berjalan dengan baik dan lancar. Dengan adanya program pengabdian kepada masyarakat ini diharapkan para pemilik usaha dapat memahami konsep bisnis di bidang pariwisata dan mengembangkan berbagai macam jejaring distribusi yang ada disekitar mereka. Saran untuk mengembangkan usaha di Dusun Kerujuk dengan strategi 7P adalah diperlukan sebuah kerja-sama dengan berbagai instansi dan pihak. Kerja-sama yang dimaksud bertujuan mengakomodir keinginan memperluas jejaring distribusi. Kesulitan optimalisasi media sosial dapat dilakukan dengan memahami keunggulan dari masing-masing media sosial yang digunakan. Hal ini 
membutuhkan pendampingan yang intensif oleh mahasiswa KKN.

\section{UCAPAN TERIMA KASIH}

Segenap tim pengabdian BOPTN-FEB-UNRAM 2018 untuk program pengabdian kepada masyarakat, dengan ini mengucapkan banyak terima kasih kepada LPPM (Lembaga Penelitian dan Pengabdian Kepada Masyarakat) Universitas Mataram yang telah mendanai program ini. Selanjutnya tidak lupa diucapkan terima kasih kepada aparat desa Kerujuk, dalam hal ini Kepala Dusun Kerujuk Barat, bapak Abdul Azis, yang telah mengkoordinir warga dan membantu kami hingga program ini dapat diselesaikan. Ucapan terima kasih juga disampaikan kepada warga dusun Kerujuk Barat yang dengan antusias mengikuti serangkaian kegiatan pengabdian kepada masyarakat ini.

\section{DAFTAR PUSTAKA}

Abdurrahman H. 2015. Manajemen Strategi Pemasaran. Bandung (ID) : Pustaka Setia. 